\title{
Development of Powered Groundnut Harvester for Small and Medium Holdings in North Kordofan State in Western Sudan
}

\author{
Moayad B. Zaied ${ }^{1}$, Ahmed M. El Naim ${ }^{2, *}$, Mohammed H. Dahab ${ }^{3}$, Afraa S. Mahgoub ${ }^{4}$ \\ ${ }^{1}$ Department of Agricultural Engineering, Faculty of Natural Resources, University of Kordofan, Elobied, Sudan \\ ${ }^{2}$ Department of Crop Sciences, Faculty of Natural Resources, University of Kordofan, Elobied, Sudan, P.O. 160. \\ ${ }^{3}$ Department of Agric. Eng., Faculty of Agriculture, University of Khartoum, Sudan \\ ${ }^{4}$ Ministry of Agriculture of North Kordofan State, Elobied, Sudan \\ *Corresponding author: naim17amn@yahoo.com
}

Received May 06, 2014; Revised May 09, 2014; Accepted May 11, 2014

\begin{abstract}
A Powered groundnut harvesting machine was designed and fabricated. The optimum machine diggers were selected using computer simulation method in ANSYS 11 program. The machine was tested in sandy and clayey sand soil. It was found that the effective time and total time recorded by the machine in sandy soil were lower than in clayey sand soil by $0.050 \mathrm{hr}$. Fuel consumption rate in sandy soil was lower than that in clayey sand soil by $0.7 \mathrm{~L} / \mathrm{ha}$. Machine field speed in sandy soil was higher than speed in clayey sand soil by $0.69 \mathrm{~km} / \mathrm{hr}$, it was also found that the values of machine theoretical field capacity, effective field capacity in sandy soil were higher than the values in clayey sand soil by 0.061 ha / $\mathrm{h}$ and $0.048 \mathrm{ha} / \mathrm{h}$ respectively while field efficiency in clayey sand soil was higher than that in sandy soil by $1.2 \%$. The differences were significant at 0.05 level and it can be concluded that the machine is efficient in harvesting the groundnut crop particularly in clayey sand soil. Hydraulic system and gear box were needed to enhance maneuverability and to control the digging speed of the machine.
\end{abstract}

Keywords: groundnut harvester, digger simulation, root crops harvesting

Cite This Article: Moayad B. Zaied, Ahmed M. El Naim, Mohammed H. Dahab, and Afraa S. Mahgoub, "Development of Powered Groundnut Harvester for Small and Medium Holdings in North Kordofan State in Western Sudan.” World Journal of Agricultural Research, vol. 2, no. 3 (2014): 119-123. doi: 10.12691/wjar-2-3-6.

\section{Introduction}

Groundnut is major root oil crop and main source of edible oil in the Sudan as well as sesame, cottonseed, and more recently sunflower. Groundnut (Arachis hypogaea L.,) is a native South American legume not known to the Old World in pre-Columbian times. Portuguese navigators are credited with introducing the crop to the western coast of Africa from Brazil, but it is not known when. West African immigrants are believed to have brought the crop to Sudan about 200 years ago, and they grew it in parts of western Sudan and along the Blue Nile. Documentation, however, is lacking [1]. The earliest forms of groundnut introduced belonged to the subspecies hypogaea. The small-seeded runner types were established on the sandy soils of western Sudan and the bunch types were grown along the Blue Nile on heavy clays. These two groups of groundnut form the land varieties in Sudan. Varieties of the subspecies fastigiata (varieties vulgaris and fastigiata) were introduced about sixty years ago as part of an improvement programme. Of these fastigiata introductions, the cultivar Barberton, primarily because of its early maturity, quickly replaced the late maturing land varieties of the runner type in the northern parts of Kordofan and Darfur [1].

The digger-shaker-windrower is used to lift groundnuts and detach them from the soil. Dig deep enough to prevent cutting pegs. Windrow-inverting attachments orient plants as they leave the shaker so pods are primarily on the top of windrows to permit greater air circulation and exposure to sunlight for a shorter drying time.

Mizrach et al [2] carried out a design of machine for digging, picking up, and separating peanut. The technique of machine used depended upon cutting the soil with peanut, plant and elevates all on screen with space equal $10.5 \mathrm{~mm}$ between the rods to loosen the soil. Japanese Trade Policy Inst. designed a vibrating potato digger, which named NIP/O. P.S. [9] The machine of one row had a little draft resistance. Ahmed and Shamsudeen [3] Developed a prototype tractor - operated groundnut digger lifter. Amin [4] developed a vibrating potato digger having field capacity of 0.31 fed / h, while field efficiency was $91.32 \%$ at forward speed of $2.1 \mathrm{~km} / \mathrm{h}$ and harvesting a feddan of $250 \mathrm{~m}$. length.

Magdy [5] stated that vibrating shares and separating table leads directly to reduce the required draft and increases the performance efficiency. Kang and Halderson [6] designed a two-row, three-point-hitch vibrating digger. Each row compared a pair of four-bar linkages to which 
two side plates are attached. A bottom plate for each row composed of a soil-digging blade, followed by soil sieving bars. These bars were rigidly attached to bottom of each pair of side plates to cut and lift the soil and also to allow for soil separation. The motion of the bottom plate was also designed to assist with soil flow. Ademilyi [7] evaluated performance of a tractor drawn groundnut digger/shaker. Kad et al[8] evaluated a performance of a developed digger that can relieve the farmer from fatigues work of hand pulling of groundnut pod and saved 11 to 13 per cent pods. The test results indicated that effective field capacity of the digger as 0.256 ha/day, with 87.98 per cent digging efficiency. Ibrahim et al. [9] developed a multi purpose digger for root crops. The machine was operated efficiently for potato at $22 \mathrm{~cm}$ harvesting depth, $2.6 \mathrm{~km} / \mathrm{h}$ forward speed and $0.31 \mathrm{rad}$ (18 deg) tilt angle with using vibrating movement and for peanut $15 \mathrm{~cm}$ harvesting depth, $2.3 \mathrm{~km} / \mathrm{h}$ forward speed and $0.21 \mathrm{rad}$ (12 deg) tilt angle with using vibrating movement. Munde et al [10] evaluated a performance of bullock drawn groundnut digger suitable for multi purpose tool carrier multipurpose tool carrier. They found that its field capacity was 0.126 ha / hr with field efficiency of $80.25 \%$ at an operating speed of $2.1 \mathrm{kmph}$. It performed the harvesting operation with a total pod loss of $8.01 \%$ and digging efficiency 92 per cent. With this digger, the cost of operation was Rs.168.30/ha for groundnut harvesting. Zhengzhou [11] demonstrated a peanut harvester which is mainly used for harvesting peanut, garlic, sweet potato, potato and other crops under the ground. Gary [12] mentioned numbers of tractor operated peanut diggers. The objective of the present work is to design and fabricate a powered groundnut harvester for small and medium size farms in North Kordofan State in Western Sudan and test its field performance in two soil types in the province.

\section{Materials and Method}

\subsection{Materials}

Materials used to conduct the present research are listed bellow

3. One cylinder internal combustion engine.

4. Power transmission differential system.

5. Steel angle bars.

6. Mild steel sheets.

7. Bearings.

8. Circular section steel bars.

9. Sprockets.

9. Spur gears.

10. Steel chains.

11. Rubber wheels.

12. Bolts, nuts and screws.

13. Metering tape.

14. Stop watch.

15. Petrol fuel.

16. Groundnut seeds.

\subsection{Method}

\subsubsection{Computer Simulation}

\subsubsection{Modeling of Diggers}

Two spear like diggers, one with $25 \mathrm{~cm}$ length and 12.5 $\mathrm{cm}$ rear base width and the other with $20 \mathrm{~cm}$ length and 10 cm base width (Figure 1 and Figure 2), were modeled in ANSYS 11 program.

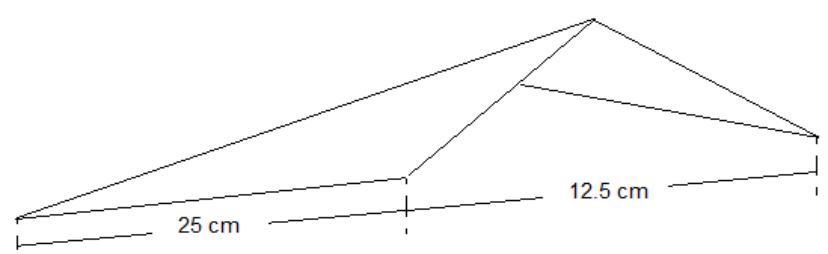

Figure 1. Digger with $25 \mathrm{~cm}$ length and 12.5 rear base width

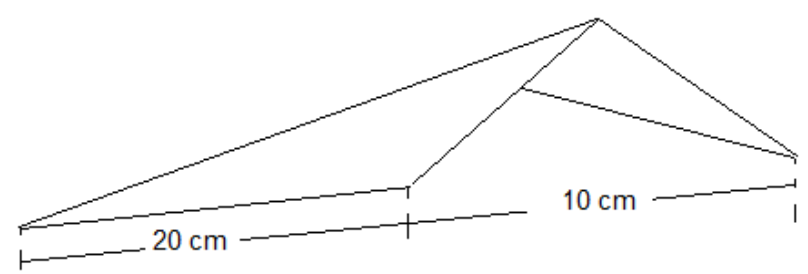

Figure 2. Digger with $20 \mathrm{~cm}$ length and 10 rear base width

\subsubsection{Material Definition for Mesh Generation}

Since digger material is 1020 steel which characterized by plasticity, stress stiffening, large deflection and large strain capability, solid 45, 8 nodes element type and elastic isotropic material model were used for meshing.

\subsubsection{Boundary Conditions}

Digger model was constrained at its top rear end and its upper surface was subjected to arbitrary load of $100 \mathrm{kPa}$.

\subsubsection{Solution for Boundary Problem and Post- Processing}

The reaction of digger is linear problem, so, the contour plot was read and the principal stress in $\mathrm{X}$ direction and shear stress in $\mathrm{XZ}$ plane were recorded for each digger design and the output of simulation were demonstrated in Figure 3, Figure 4, Figure 5, Figure 6 and Table 1.

Table 1. Stress distribution on surface of different digger

\begin{tabular}{cccc}
\hline $\begin{array}{c}\text { Digger } \\
\text { length } \mathrm{cm}\end{array}$ & $\begin{array}{c}\text { Rear base } \\
\text { width cm }\end{array}$ & $\begin{array}{c}\text { Stress in X } \\
\text { direction kP }\end{array}$ & $\begin{array}{c}\text { Shear stress on XZ } \\
\text { plane kP }\end{array}$ \\
\hline 25 & 12.5 & 136.89 & 46.33 \\
20 & 10 & 27.66 & 12.48 \\
\hline
\end{tabular}

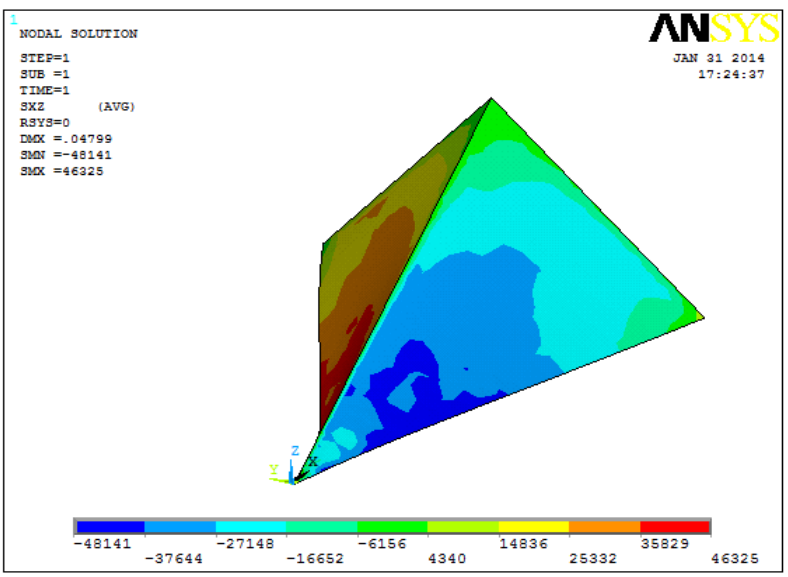

Figure 3. Shear stress in XZ plane on $25 \mathrm{~cm}$ long digger 


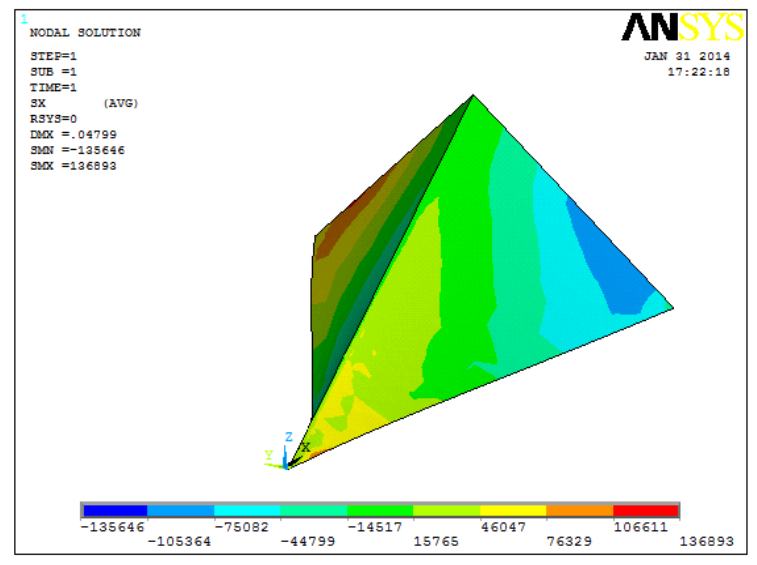

Figure 4. Stress in $\mathrm{X}$ direction on $25 \mathrm{~cm}$ long digger

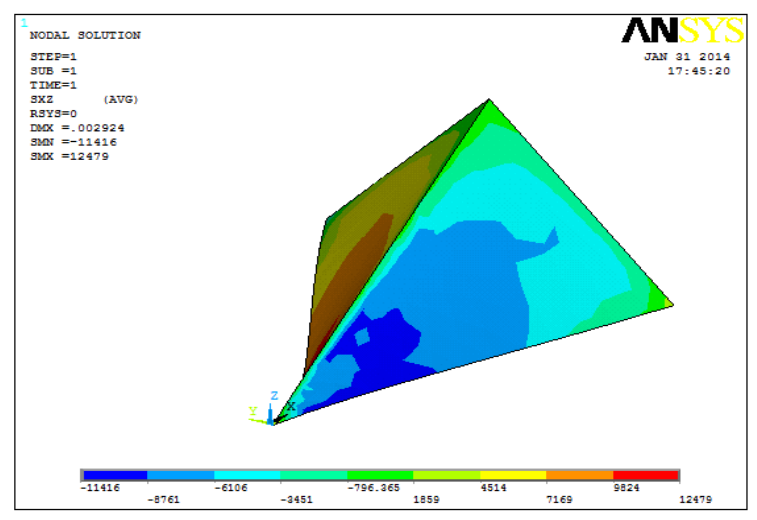

Figure 5. Shear stress in XZ plane on $20 \mathrm{~cm}$ long digger

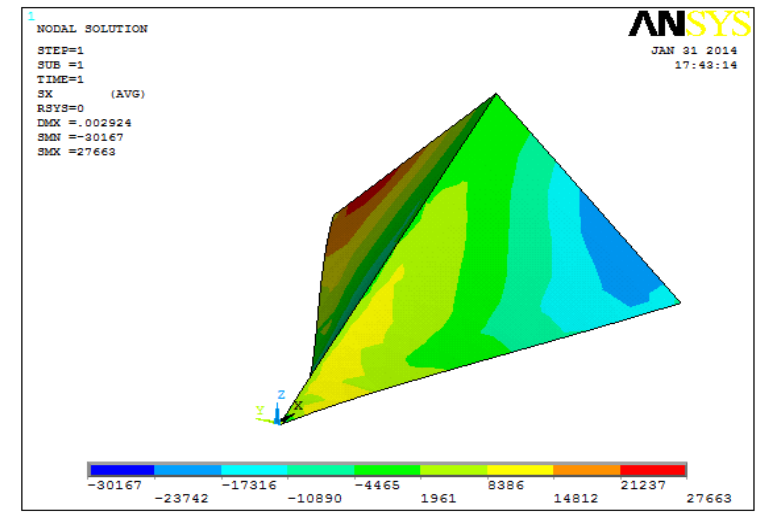

Figure 6. Stress in $\mathrm{X}$ direction on $20 \mathrm{~cm}$ long digger

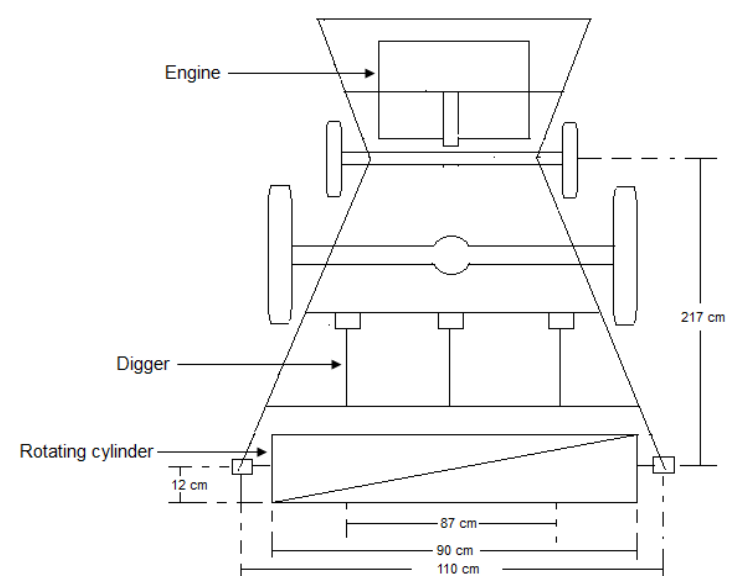

Figure 7. Machine dimensions

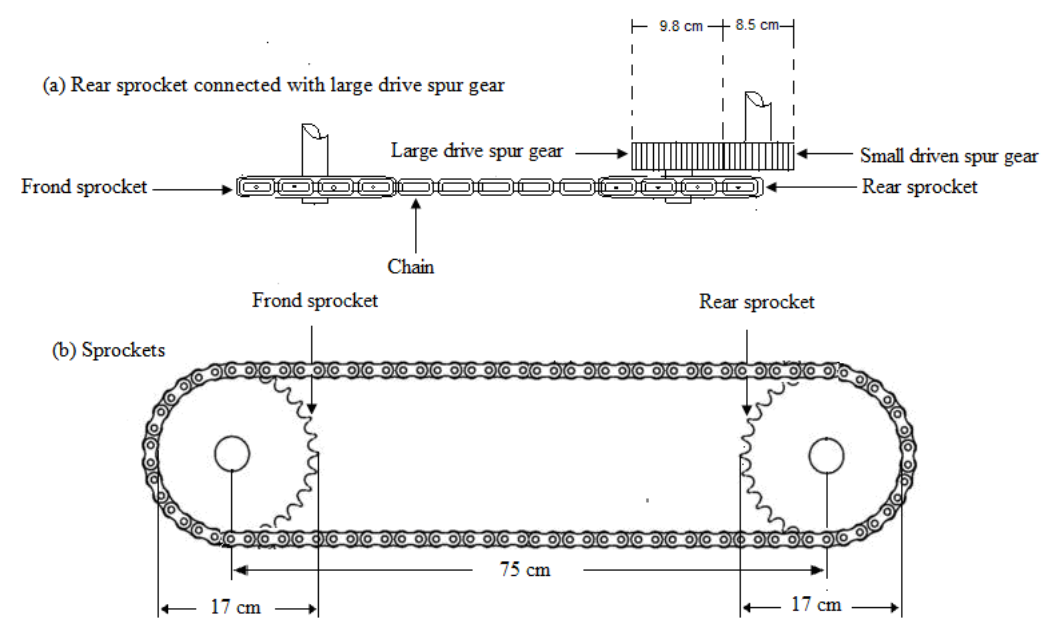

Figure 8. Motion transmission system

Table 2. Specification of the machine

\begin{tabular}{cc}
\hline Engine power & $25 \mathrm{~kW}$ \\
Weight & $86 \mathrm{~kg}$ \\
Power transmission & Chain, sprocket and gears \\
Machine length & $217 \mathrm{~cm}$ \\
Machine width & $110 \mathrm{~cm}$ \\
Effective width & $87 \mathrm{~cm}$ \\
Rear height of the frame & $40 \mathrm{~cm}$ \\
Frond height of the frame & $30 \mathrm{~cm}$ \\
Number of diggers & 3 \\
Digger rake angle & 250 \\
Digger length & $20 \mathrm{~cm}$ \\
Digger base width & $10 \mathrm{~cm}$ \\
Length of rotating cylinder & $90 \mathrm{~cm}$ \\
Diameter of rotating cylinder & $25 \mathrm{~cm}$ \\
Diameter of sprocket & $17 \mathrm{~cm}$ \\
Diameter of small spur gear & $8.5 \mathrm{~cm}$ \\
Diameter of large spur gear & $9.8 \mathrm{~cm}$ \\
\hline
\end{tabular}

\subsubsection{Machine Fabrication}

The results of computer simulation in Table 1 showed that the optimum dimensions of digger that demonstrated the lowest stresses distribution were $20 \mathrm{~cm}$ length and 10 $\mathrm{cm}$ base width, therefore, these dimensions were adopted to manufacture the machine diggers. The machine with specifications in Table 2 was fabricated in a workshop of agricultural machineries in Elobied Industrial Area. The machine and motion transmission system part and dimensions were shown in Figure 7 and Figure 8 (a and b)

\subsubsection{Soil Test}

Soil samples were taken from two different locations in North Kordofan State at depth $30 \mathrm{~cm}$, the moisture content 
on dry base and soil bulk density for the samples were determined. Tri-axial soil test apparatus and shear box were used to measure soil cohesion and internal angle of friction, while soil adhesion measurement apparatus was used to determine soil adhesion pressure with steel and the soil physical and mechanical properties were shown in Table 1.

\begin{tabular}{ccc}
\multicolumn{3}{c}{ Table 3. Soil physical and mechanical properties } \\
\hline Properties & $\begin{array}{c}\text { First location } \\
\text { (sandy) }\end{array}$ & $\begin{array}{c}\text { Second location } \\
\text { (clayey sand) }\end{array}$ \\
\hline Moisture (\%) in d.b & 19.2 & 22.7 \\
Bulk density $\left(\mathrm{g} / \mathrm{cm}^{3}\right.$ ) & 1.31 & 1.48 \\
Internal angle of friction & 34.0 & 20.0 \\
(deg.) & 5.0 & 18.3 \\
Cohesion (k Pa) & 1.12 & 1.47 \\
Steel adhesion (k Pa) & & \\
\hline
\end{tabular}

\subsubsection{Measurements of Field Performance Parameters}

The field work was conducted in two the locations, the experiment was carried out in 8 plots grown with groundnut in each location, the area of the plot was $100 \mathrm{~m}$ $\mathrm{x} 4.6 \mathrm{~m}$.

\subsubsection{Measurement of Time}

The machine was operated in the plot and the time was recorded using stop watch. The turning time at ends of the plot was determined.

Total time was computed by adding effective time to turning time and other field stops time.

\subsubsection{Fuel Consumption Measurement}

The fuel consumption rate was detected as follows:

The machine started working the plot with full tank, after finishing the plot, the tank was refilled using measuring cylinder. The amount of fuel used to refill the fuel tank was recorded. The fuel consumption rate was calculated as follows:

$$
F C R=\frac{C_{R}}{A} \times C_{1}
$$

Where,

FCR = fuel consumption rate, $\mathrm{L} /$ ha.

$\mathrm{CR}=$ reading of cylinder, $\mathrm{ml}$.

$\mathrm{A}=$ area, $\mathrm{m} 2$.

C1 = conversion factor, [10].

\subsubsection{Measurement of Speed}

The digging velocity was the calculated as follow

$$
S=\frac{D}{t} \times C_{2}
$$

Where,

$\mathrm{S}=$ digging speed, $\mathrm{km} / \mathrm{h}$.

$\mathrm{D}=$ travelling distance, $\mathrm{m}$.

$\mathrm{t}=$ time, $\mathrm{s}$.

C2 = conversion factor, [3.6].

\subsubsection{Measurement of Theoretical Field Capacity}

Theoretical field capacity in each plot was computed using the following equation

$$
T F C=\frac{S \times W}{C_{3}}
$$

Where,

TFC = theoretical field capacity, ha/h.

$S=$ digging speed, $\mathrm{km} / \mathrm{h}$.

$W=$ working width, $\mathrm{m}$.

$C_{3}=$ conversion factor, [10].
2.2.4.5. Measurement of Effective Field Capacity

Effective field capacity was calculated as follows

$$
E F C=\frac{A}{T} \times C_{4}
$$

Where,

$E F C=$ effective field capacity, ha/h.

$A=$ plot area, $\mathrm{m}^{2}$.

$T=$ time, sec.

$C_{4}=$ conversion factor, [0.36].

2.2.4.6. Measurement of Field Efficiency

$$
F E=\frac{E F C}{T F C} \times 100
$$

\section{Results and Discussion}

The views and motion transmission system of the fabricated harvesting machine were shown in Plate 1, Plate 2 and Plate 3. Field time and fuel consumption rate were demonstrated in Table 4 while field speed, field capacities and efficiency were shown in Table 5.

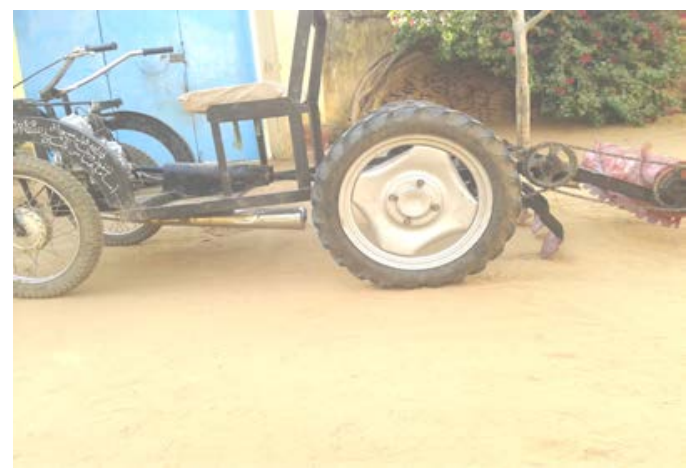

Plate 1. Side view of the machine (diggers and rotating cylinder at raised position)

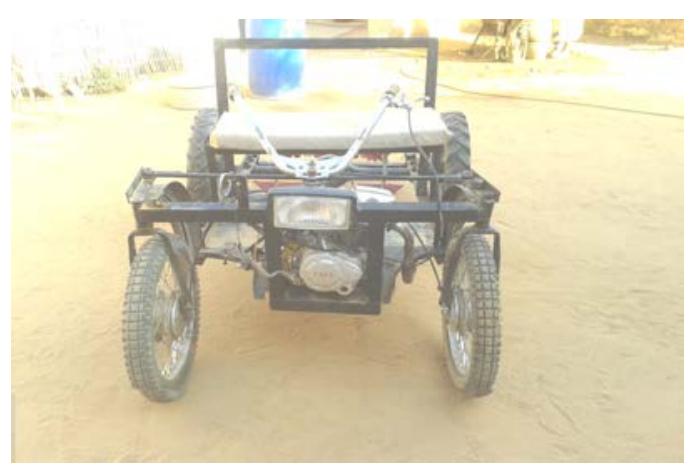

Plate 2. Frond view of the machine

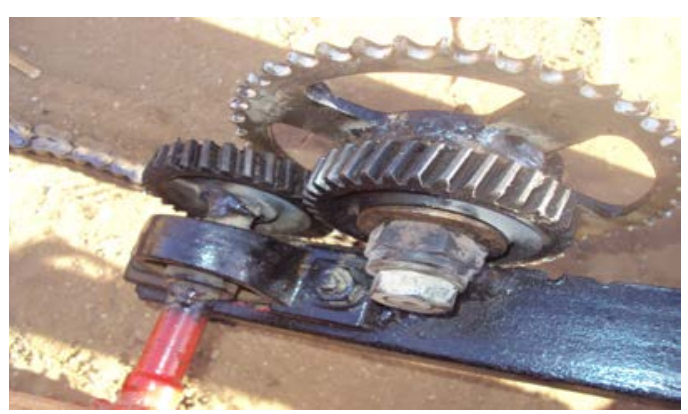

Plate 3. Second phase motion transmission (from middle gear to rotating cylinder) 
Table 4 showed that the effective time and total time recorded by the machine in sandy soil were lower than effective time and total time recorded in clayey sand soil by $0.050 \mathrm{hr}$. It was also demonstrated that fuel consumption rate in sandy soil was lower than that in clayey sand soil by $0.7 \mathrm{~L} / \mathrm{ha}$. Since the clayey sand soil is characterized by higher bulk density, cohesion and adhesion force as compared to sandy soil, therefore, the field time and fuel consumption rate in clayey soil were higher than in sandy soil and the differences between soil types were found to be significant at 0.05 level.

Table 4. Field time and Fuel consumption in two locations

\begin{tabular}{ccccc}
\hline Locations & $\begin{array}{c}\text { Effective } \\
\text { time h }\end{array}$ & $\begin{array}{c}\text { Turning } \\
\text { time h }\end{array}$ & $\begin{array}{c}\text { Total } \\
\text { time h }\end{array}$ & $\begin{array}{c}\text { Fuel } \\
\text { consumption L / } \\
\text { ha }\end{array}$ \\
\hline $\begin{array}{c}\text { Sandy soil } \\
\text { Clayey } \\
\text { sand soil }\end{array}$ & $0.186^{\mathrm{a}}$ & $0.011^{\mathrm{a}}$ & $0.197^{\mathrm{a}}$ & $6.1^{\mathrm{a}}$ \\
\hline
\end{tabular}

"Each value is an average of three replicates.

${ }^{*}$ Values in column sharing same superscript letter show no significant difference at 0.05 level as separated by Tukey's Test.

Table 5. Field speed, capacities and efficiency in two locations

\begin{tabular}{ccccc}
\hline Locations & $\begin{array}{c}\text { Speed } \\
\mathrm{km} / \\
\mathrm{h}\end{array}$ & $\begin{array}{c}\text { Theoretical } \\
\text { capacity ha / h }\end{array}$ & $\begin{array}{c}\text { Effective } \\
\text { capacity ha / } \\
\mathrm{h}\end{array}$ & $\begin{array}{c}\text { Field } \\
\text { efficiency \% }\end{array}$ \\
\hline $\begin{array}{c}\text { Sandy soil } \\
\text { Clayey } \\
\text { sand soil }\end{array}$ & $\begin{array}{c}3.23^{\mathrm{a}} \\
2.54^{\mathrm{b}}\end{array}$ & $0.281^{\mathrm{a}}$ & $0.234^{\mathrm{a}}$ & $83.3^{\mathrm{a}}$ \\
\hline
\end{tabular}

*Each value is an average of three replicates.

* Values in column sharing same superscript letter show no significant difference at 0.05 level as separated by Tukey's Test

Machine field speed (Table 5) in sandy soil was higher than speed in clayey sand soil by $0.69 \mathrm{~km} / \mathrm{hr}$, the lower speed in clayey sand soil may be due to higher resistance force resulted form higher shear strength of that cohesive soil which increased the wheel slippage as compared to sandy soil. it was also found that the values of machine theoretical field capacity, effective field capacity (Table 5) in sandy soil were higher than the values in clayey sand soil by 0.061 ha / $h$ and 0.048 ha / h respectively while field efficiency in clayey sand soil was higher than that in sandy soil by $1.2 \%$, the differences were significant at 0.05 level. Amin [4] developed a vibrating potato digger having field capacity of 0.31 fed / h, while field efficiency was $91.32 \%$ at forward speed of $2.1 \mathrm{~km} / \mathrm{h}$ and harvesting a feddan of $250 \mathrm{~m}$. length. Magdy [5] stated that vibrating shares and separating table leads directly to reduce the required draft and increases the performance efficiency. A multi purpose digger developed by Ibrahim et al. [9] for root crops. The machine was operated efficiently for potato at $22 \mathrm{~cm}$ harvesting depth, $2.6 \mathrm{~km} \mathrm{/} \mathrm{h} \mathrm{forward}$ speed and 0.31 rad ( $18 \mathrm{deg}$ ) tilt angle with using vibrating movement and for peanut $15 \mathrm{~cm}$ harvesting depth, $2.3 \mathrm{~km}$ / h forward speed and 0.21 rad (12 deg) tilt angle with using vibrating movement. It was deduced that it is not necessary to have a higher speed to obtain a higher field efficiency, it is known that the higher speed will reduce the total field time a thing which increases the effective field capacity but at the same time the theoretical field capacity will increase, therefore, field efficiency may reduced.

It can be concluded that the machine is effective in harvesting the groundnut crop particularly in clayey sand soil.

\section{Conclusions}

Self propelled groundnut harvesting machine was designed, fabricated and tested in sandy and clayey sand soil. Computer simulation method was applied to select the optimum design of machine diggers before been fabricated. The machine can be used to harvest root crops other than groundnut. The drudgery of field work will be reduced and labor shortage problem in the State will be overcome by the machine. The field efficiency of the machine in clayey sand soil is higher than in sandy soil but in clayey sand soil the machine consumed more fuel.

The machine is needed to be equipped with a hydraulic system as well as gear box to enhance its maneuverability and to control the digging speed.

\section{References}

[1] Mahmoud, A. M. Mohamed, O. K. Mohamed, A. K. Abdel Moneim, B. E. Hassan, A. M. El Tahir, I.M. “Crops of Sudan”. Country Report” FAO International Technical Conference on Plant Genetic Resources. Khartoum, March 1995 p: 1-83, 1995.

[2] Mizrach, A. Margolin, A., Feller, R. and Alper, Y. Peanut salvage machine for sandy loam and clay soils. Trans. ASAE, 26 (2): 389391, 1983

[3] Ahmed, D. and Shamsudeen, V.G. "Development of a prototype tractor-operated groundnut digger” lifte. Peratanika, 10 (2): 219223, 1987

[4] Amin, E. "Mechanization for potato production on small farms". Ph.D.Thesis, Agric. Eng. Dept Fac. of Agric., Mansoura Univ, 1990.

[5] Magdy, M.A. A. "Mechanization of potato harvesting”. Ph.D Agric. Eng. Al-Azhar Uni., 1991.

[6] Kang, W.S., Halderson, J.L. "A vibratory two-row potato Digger" Applied Engineering in agriculture. 7 (6): 683-687 1991.

[7] Ademilyi, Y.S. James, D., Ozumba, I. C, Olowonibi, M. M. "Performance evaluation of a Tractor Drawn Groundnut Digger/Shaker”. NCAM Research Publication, P: 115 - 122, 2004.

[8] Kad, V.P., Nikam, S.P, Salve, V.A. "Performance evaluation of power tiller drawn groundnut digger”. International journal of Agricultural Engineering, 1 (2):107-109, 2008.

[9] Ibrahim, M. M., Amin, E., Farag, A. "Developing a Multi Purpose Digger for Harvesting Root Crops”. Misr J. Ag. Eng., 25 (4): 1225-1239, 2008.

[10] Munde, P.A Nadre, R.G., Sawant, B.P. "Performance evaluation of bullock drawn groundnut digger suitable for MAU multi purpose tool carrier". International journal of Agricultural Engineering, 2 (1): 157-159, 2009.

[11] Zhengzhou, G. "Peanut harvester, Peanut groundnut harvester". P: 1-10. Machinery CO. LTD, 2010.

[12] Gary, R. "Improving Harvesting Effectiveness for Peanut Diggers". North Carolina State University, Department of Biological and Agricultural Engineering. Report, p: 1-2, 2011. 